\title{
Empirical Research on Influencing Factors of Human Resources Management Outsourcing Degree*
}

\author{
Lihua Zhao ${ }^{1}$, Jiang $\mathrm{Li}^{2}$, Jing $\mathrm{Li}^{1}$ \\ ${ }^{1}$ Economics and Management School, Tianjin University of Technology and Education, Tianjin, China; ${ }^{2}$ Economics and Manage- \\ ment School, Beijing University of Posts and Telecommunications, Beijing, China. \\ Email: buptjl@yahoo.cn, lijingjing@live.com
}

Received 2013

\begin{abstract}
In this paper we review the human resources management outsourcing research in domestic and overseas, establish a model and then propose research hypotheses. With the empirical research method, we take the questionnaire investigation and research on enterprise human resources department manager or staff, and then take statistical analysis to them with SPSS software. From the research results, we come to a conclusion that top intervention, strategic position of the function and the asset specificity has more significant impact to enterprise human resources management outsourcing degree, thus, providing reference opinions for enterprise human resources outsourcing.
\end{abstract}

Keywords: Human Resources Management Outsourcing; Outsourcing Degree; Influence Factor

\section{Introduction}

With the increasingly fierce market competition, the enterprise faces more complex and dynamic business environment, if it wants to get the survival and development space, the enterprise must focus on its resources, develop its core business and make enterprise's core competitive ability. Therefore, many enterprises have broken traditional organization structure which is large and all inclusive; they complete some non-core business using the outside resources, so outsourcing arises at the historic moment. At one time an organization may have many different human resources activities so that it is hard to divide it just with all outsourcing or all not outsourcing, therefore, in our view it has more practical meaning to research on outsourcing degree other than studying whether it is outsourcing.

\section{Literature Review}

\subsection{Human Resources Management Outsourcing}

For human resources outsourcing, different scholars have different points of view. Switser (1997) points out that the trend of human resources management outsourcing is from the previous view of cost savings to obtain competitive advantage; he forecasts that outsourcing is the

"Philosophy Social Science Project: Tian Jin college graduates employment stability study based on the perspective of psychological capital in occupation adaptation period ( TJSR11 - 003 ). only the biggest growth opportunities of the professional services company in the next 10 years. Lever defines the human resource functions outsourcing as "act that enterprise let certain human resource functions to external service providers complete ". GreeL Younghlood and Gray hold the view that: "the human resource functions outsourcing is that human resources tasks are repeated by external partners. Mary. F. Cook defines human resource functions outsourcing as: "let the third party service provider or services seller provide a continuous supply of human resources management service, in the past this management activities is usually taken by enterprise internal departments concerned. Service providers will sign contract to manage a particular human resources activity, they provide the scheduled service and charge established service fee. Domestic scholars Liu Bang put forward the concept: "human resource functions outsourcing is maintaining a long-term contract of new human resources operational model to get certain HR business service from outside specialized service suppliers". An Yingmin thinks: "so-called human resource functions outsourcing is that the enterprise puts more energy on the core of human resources management work, and outsources some complex and procedural strong daily routine work of human resources management to the professional human resources management service agencies."

In our view the human resources management outsourcing is one management mode that the enterprise outsources some repetitive, complex affairs of human 
resources management to professional institutions to reduce cost, and makes human resource managers can concentrate on the enterprise human resources management planning and policy from the strategy angle.

\subsection{Human Resources Management Outsourcing Degree}

At one time an organization may have many different human resources activities so that it is hard to divide it just with all outsourcing or all not outsourcing. Organizations should choose scale of human resources management outsourcing depending on different demands. Therefore, it is more realistic to replace whether it is with outsourcing degree. Human resources management outsourcing degree is degree that one enterprise entrusts human resource management functions to the external professional organization. in the classification of Groweretal way the level of management, namely to be measured by enterprise human resources management activities decision-making power belongs to contractors or the external enterprise as well as the degree of outsourcing comparing to other enterprise.

High transaction costs, internalization, low transaction costs, different degree of outsourcing; The asset specificity is high, the internalization degree is higher, low level of outsourcing (Alpar\&Sallaria, Anbertetal, DeLoff, Klepper \& Jones); Mcfarlan, Nolan thinks cost, quality, service departments provide, competitive pressure, business restructuring are influence factors of outsourcing degree. High business structure, high difference and discretion between functions and organization, enterprise experience and management ability will lead to high outsourcing degree. Lacity, Wilcocks, Feeny thinks the contribution to enterprise status and enterprise operation can influent the outsourcing degree. Business that have little contribution to enterprise status can be outsourced integrality or partly according to the contribution to the enterprise operation; Michacl. Earl thinks performance level of department operation also influents enterprise degree. Poor performance level, low outsourcing degree.

Based on the summary and induction of predecessors' achievements, Ji Zhijian Su Jingqin and other scholars conclude the degree of influence factors of outsourcing in their paper: subject (enterprise) ability strength and object (business) nature. The research results indicate that: all kinds of size enterprise can adopt outsourcing strategy, if enterprise asset specificity is high and ability level is low, the outsourcing level should not be too big; when the enterprise ability develops to a certain height, its constraint to the outsourcing degree will reach the steady state.

\section{Study Method and Data Colleting}

\subsection{Model Establishment}

Although there are many documents for human resources management outsourcing research in domestic and international, but they mainly focus on outsourcing mode, risks and performance. They rarely pay attention to the outsourcing degree. Therefore, in this paper we want to have an empirical analysis of the influencing factors of human resource management outsourcing degree through questionnaire investigation to the enterprise human resources department supervisor or staff and establish the model that can reflect influencing factors of human resource management outsourcing degree on the basis of previous studies.

This model uses Ji Zhijian and Su Jingqin (2006) the idea for reference and summarizes the influencing factors of human resources management outsourcing for the main factors and object factors. On one hand, according to the transaction cost theory as well as the core competitiveness theory, set the transaction characteristics (uncertainty, the asset specificity and trade frequency), and business characteristics (strategic position of business) as object influencing factors; On the other hand, in this paper we adopt some research results of Xu Qiyi (1999), set the company size, attention level of managers and outsourcing experience as the main influencing factors, thus construct the model framework. From the influencing factors many previous studies involved. In this paper we select some typical and high testability factors according to its theory roots, research purpose as well as characteristics of human resource management field, and then classify and investigate them. On the other hand, previous similar empirical researches mainly use unary or multiple linear regression method to test that, while we use multiple econometrics mode $l$ to test it trying to draw higher fitting degree model to make the final conclusion more accurate.

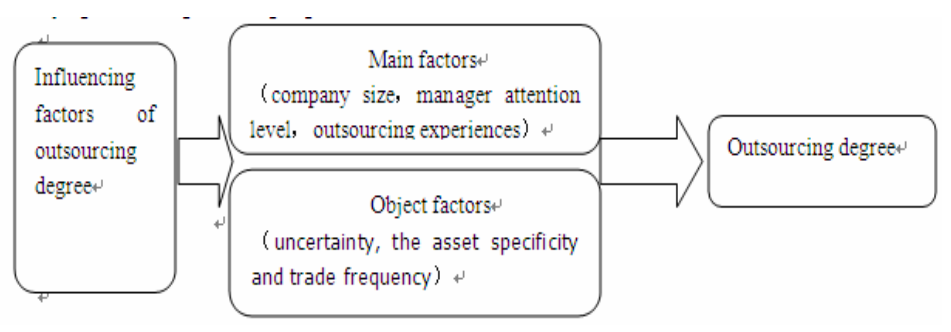

Figure 1. Human resource management outsourcing degree influencing factors model. 


\subsection{Proposing Research Problem and Hypothesis}

Based on the transaction cost theory, core competitiveness theory and related theory of outsourcing degree, in this paper we propose hypothesis about the different inflections of kinds of influencing factors on human resource management outsourcing degree mainly from three aspects, trading characteristics, business characteristics and enterprise features, then we construct the model:

1) Influence of trading characteristics on outsourcing degree

According to the transaction cost theory, transaction characteristics can be measured from three aspects, asset specificity, uncertainty and trade frequency. Transaction costs increase as asset specificity level and uncertainty level increase, regular trading is likely to reduce transaction costs. From that point, in order to study the influence of asset specificity, uncertainty and transaction frequency on the enterprise human resources management outsourcing, we put forward the following research problems and hypothesis:

Problem1: Study the influence of transaction characteristics on the enterprise human resources management outsourcing

Hypothesis 1: transaction characteristics of enterprise human resources management outsourcing has significant correlation with its information system outsourcing degree

Hl1:Asset specificity of enterprise human resources management system has significant correlation with its human resource functions outsourcing degrees

H12:Uncertainty of enterprise human resources management environment has significant correlation with its human resource functions outsourcing degrees

H13:Outsourcing frequency of enterprise human resources management function has significant correlation with its human resource functions outsourcing degrees

2) Influence of business characteristics on the outsourcing degree

Here the business characteristics refer to the strategic position of a human resources management function in the company. That is the degree of its core capability. Generally speaking, we judge a business core competence degree depending on three characteristics, namely the uniqueness, valuable and ductility. In light of this, studying influence of strategic position of enterprise human resources management business on human resources management outsourcing degree, we put forward the following research problems and hypothesis:

problem2: study the influence of business characteristics on the enterprise human resources management outsourcing degree

Hypothesis 2: Strategic position of enterprise human resources management functions has significant correlation with its information system outsourcing degrees

H21: Strategic position of enterprise human resources management functions has significant correlation with its information system outsourcing degrees

3) Influence of enterprise characteristics on outsourcing degree

A outsourcing decision is not only influenced by the business itself, that is the effect of outsourcing object, but also influenced by the main body from outsourcing, therefore, as an enterprise's strategic decision, outsourcing degrees strategy is in a great extent influenced by the enterprise itself characteristics. According to the topic of this paper and measurable request, in this research we use enterprise scale, manager attention level and outsourcing experience to describe the characteristics of the enterprise. Firstly, allocations of human resource management will influent the enterprise outsourcing degree. Secondly, the degree of top managers' intervention indicates value degree and the strength of the execution. Outsourcing experience is also a factor an enterprise must take into account when it makes the outsourcing decision, studying the influence on human resources management outsourcing degree; we put forward the following research problem and hypothesis:

problem3: study the influence of business characteristics on its human resources management outsourcing degree

Hypothesis 3: Strategic position of enterprise human resources management functions has significant correlation with its information system outsourcing degree

H31: Enterprise scale has significant correlation with its information system outsourcing degree

H32: The degree of top managers' intervention to human resources management activity has significant correlation with outsourcing degree

H33: Outsourcing experience of enterprise has siginificant correlation with its human resources management outsourcing degree

\subsection{Questionnaire Design and Data Analysis}

1) Questionnaire design

In the form Questionnaire mainly takes Richter (Ukcrt) five-point scale for reference. According to the different levels of investigated-things, they are divided into five levels to let the objects choose. As for the contents we take part of Xu Qiyi's scale for reference and make some modification for practical needs. The questionnaire is mainly divided into three parts, including Enterprise current situation, subject factors and object factors. Enterprise situation: including enterprise basic information, the main reason of enterprise human resources management outsourcing. Subject factors: including outsourcing degree, manager intervention degree and outsourcing 
experience. The object factors: including outsourcing degree, asset specificity, uncertainty and strategic position of business.

The enterprises we survey are mainly more than 100 people's large and medium-sized enterprises. Most of them have been established for five years. We give out 150 questionnaires in the study and recycle 72, of which the effective questionnaires are 67; the recovery is $48 \%$, and the effective rate is $44.7 \%$.

2) The reliability and validity analysis and related analysis of the scale

According to Cronbach's alpha coefficient and reliability table (Table 1, Table 2), we can see that the a coefficient of these factors and the whole a coefficient are in a reliable range.

From the different validity of the tables show (Table 3, Table 4), we can learn that correlation coefficient between two factors is mainly low to moderate, that is to say said it is really different between the two.

3) The validation of the hypothesis

In this paper we mainly apply multiple linear regression models, totally elastic model and half elastic models of multiple regression analysis model to analyze the data, the following is variable Setting:
Subject factors regression model includes following variables: Outsourcing degree(Y1), Enterprise scale (x1), manager intervention degree(x2), Outsourcing experience(x3)

Object factors regression model includes following variables: Outsourcing degree (Y2)、Asset specificity(a1), Uncertainty(a2), Frequency(a3), Strategic position(a4) the regression equations of subject factors and object factors of this paper can be respectively written as:

$$
\begin{aligned}
& \mathrm{Y}_{7}=\mathrm{h}_{0}+\mathrm{h}_{1} \operatorname{InX}_{1}+\mathrm{h}_{2} \operatorname{Inx}_{2}+\mathrm{h}_{3} \operatorname{Inx}_{3} \\
& \mathrm{Y}_{8}=\mathrm{i}_{0}+\mathrm{i}_{1} \text { Ina }_{1}+\mathrm{i}_{2} \text { ina }_{2}+\mathrm{i}_{3} \text { Ina }_{3}+\mathrm{i}_{4} \text { Ina }_{4}
\end{aligned}
$$

According to the results of regression (Table 5 and Table 6) through the inspection top intervention accesses into the linear equation, and the other two variables are rejected. After the adjustment the multiple decision coefficients R2 is 0.339 , showing that regression equation can reveal $33.9 \%$ of the total variance in outsourcing degrees; F test and t test both achieve significant level, illustrating that linear regression equation of the model has statistical significance, the standard regression equation is:

Human resources management outsourcing degree = $0.591 \times$ top executives intervention degree

Table 1. Reliability test results of subject factors.

\begin{tabular}{llll}
\hline & $\begin{array}{l}\text { after deleting this question } \\
\text { the average of the Scale }\end{array}$ & $\begin{array}{l}\text { after deleting this question the } \\
\text { variance of the scale }\end{array}$ & $\begin{array}{l}\text { after deleting this question the a } \\
\text { coefficient of the scale }\end{array}$ \\
\hline Outsourcing degree & 10.3731 & 5.2981 & 0.5674 \\
Enterprise scale & 8.8657 & 6.2999 & 0.6302 \\
manager intervention & 9.4478 & 5.0389 & 0.5695 \\
Outsourcingexperience & 9.7761 & 7.2673 & 0.7835 \\
Reliability coefficien: 0.7124 & & & \\
\hline
\end{tabular}

\begin{tabular}{|c|c|c|c|}
\hline & $\begin{array}{l}\text { after deleting this question } \\
\text { the average of the Scale }\end{array}$ & $\begin{array}{l}\text { after deleting this question the } \\
\text { variance of the scale }\end{array}$ & $\begin{array}{l}\text { after deleting this question the a } \\
\text { coefficient of the scale }\end{array}$ \\
\hline Outsourcingdegree & 11.1433 & 6.1231 & 0.5415 \\
\hline Asset specificity & 9.7761 & 5.3240 & 0.4836 \\
\hline Uncertainty & 9.6418 & 7.1527 & 0.6846 \\
\hline Frequency & 9.5463 & 5.5300 & 0.4954 \\
\hline Strategic position & 10.9134 & 7.1991 & 0.6494 \\
\hline
\end{tabular}

Table 2. Reliability test results of object factors.

Table 3. Correlation analysis of subject factors.

\begin{tabular}{ccc}
\hline Enterprise scale & $\begin{array}{c}\text { Manager } \\
\text { intervention }\end{array}$ & $\begin{array}{c}\text { Outsourcing } \\
\text { experience }\end{array}$ \\
\hline Enterprise scale & 1.000 & \\
$\begin{array}{c}\text { Manager } \\
\text { intervention } \\
\begin{array}{c}\text { Outsourcing } \\
\text { experience }\end{array}\end{array}$ & $0.5709(*)$ & 1.000 \\
\hline
\end{tabular}

\begin{tabular}{|c|c|c|c|}
\hline $\begin{array}{c}\text { Asset } \\
\text { specificity }\end{array}$ & $\begin{array}{l}\text { Uncertainty } \\
\text { Frequency }\end{array}$ & Strategic & position \\
\hline Asset specificity & 1.000 & & \\
\hline Uncertainty & 0.100 & 1.000 & \\
\hline Frequency & $0.823(* *)$ & 0.131 (*) & 1.000 \\
\hline Strategic position & 0.086 & $0.116(*)$ & $0.051 \quad 1.000$ \\
\hline
\end{tabular}

Table 4. The correlation analysis of object factors.

* Related significance when significant level is $0.05 ; * *$ Related significance when significant level is 0.01 . 
The results of regression analysis suggest that the intervention of enterprise top executives to human resources management outsourcing activities will have positive influence for the outsourcing degree, that is to say enterprise human resources management outsourcing degree largely depends on top manager's attitude, its decision-making power is more concentrated, and the course is from up to down. On the other hand, the enterprise scale and outsourcing experience these two factors are refused, showing that the development of human resources management outsourcing has not only confined to large enterprises to participate in; all kinds of scale enterprise gradually begin to recognize its value and significance and take different strategies of outsourcing degree according to its practical needs.

According to SPSS data of Table 7 and Table 8, after the adjustment decision coefficient R2 of model 1 (multiple linear regression model) is the highest, that is the best fitting degree. So we choose analysis results of the mode to test hypothesis of this paper. According to the results of gradual regression, strategic position and the asset specificity of single human resources management business pass the inspection into the linear equation, while the other two variables are rejected. After the adjustment multiple decision coefficients R2 is 0.374 , showing that regression equation can reveal $37.4 \%$ of the total variance in outsourcing degrees; $\mathrm{F}$ test and $\mathrm{t}$ test both achieve significant level, illustrating that linear regression equation of the model has statistical significance, the standard regression equation is:

Human resources management outsourcing degree $=0.382 \times$ Strategic position $+0.332 x$ Asset specificity

Table 5. Regression analysis results of subject factors.

\begin{tabular}{|c|c|c|c|c|}
\hline Model & & bject factor & & standard \\
\hline \multirow{3}{*}{$\begin{array}{l}\text { mode } 11 \text { (multiple linear } \\
\text { regression model }\end{array}$} & $\begin{array}{l}\text { Enterprise } \\
\text { scale (x1) }\end{array}$ & $\begin{array}{l}\text { Top manager } \\
\text { intervention }(\mathrm{x} 2)\end{array}$ & $\begin{array}{l}\text { Outsourcing } \\
\text { experience (x3) }\end{array}$ & Regression standard \\
\hline & $a_{1}=0$ is refused & $\mathrm{a}_{2}=0.591$ & $a_{3}=0$ is refused & \multirow{8}{*}{$\begin{array}{l}\text { The standard Into the equation is: statistic } \\
\text { probable value of } F \text { should }<=0.050 \text {; the } \\
\text { standard to remove is: }>=0.100\end{array}$} \\
\hline & $\mathrm{Y}_{1}=0.591 \mathrm{x}_{2}$ & & & \\
\hline \multirow{2}{*}{$\begin{array}{l}\text { mode12(Bi-logarithm } \\
\text { model) }\end{array}$} & $\mathrm{c}_{1}=0$ is refused & $c_{2}=0.572$ & $c_{3}=0$ is refused & \\
\hline & $\operatorname{InY}_{3}=0.572 \operatorname{Inx} x_{2}$ & & & \\
\hline \multirow{2}{*}{$\begin{array}{l}\text { mode13(logarithm-Linear } \\
\text { model) }\end{array}$} & $\mathrm{f}_{1}=0$ is refused & $\mathrm{f}_{2}=0.587$ & $\mathrm{f}_{3}=0$ is refused & \\
\hline & $\operatorname{InY}_{5}=0.587 x_{2}$ & & & \\
\hline \multirow{2}{*}{$\begin{array}{l}\text { mode14(linear-logarithm } \\
\text { model) }\end{array}$} & $\mathrm{h}_{1}=0$ is refused & $h_{2}=0.562$ & $\mathrm{~h}_{3}=0$ is refused & \\
\hline & $\mathrm{Y}_{7}=0.562 \operatorname{Inx}_{2}$ & & & \\
\hline
\end{tabular}

Table 6. Regression analysis coefficients of subject factors.

\begin{tabular}{|c|c|c|c|c|c|c|c|}
\hline & $\begin{array}{l}\text { Multiple related } \\
\text { coefficient R }\end{array}$ & $\begin{array}{l}\text { determination } \\
\text { coefficient }^{2}\end{array}$ & $\begin{array}{l}\text { determination coefficient } \\
\text { after adjusted } \mathrm{R}^{2}\end{array}$ & F value & F significant & $\mathrm{T}$ value & $\mathrm{T}$ significant \\
\hline model1* & 0.591 & 0.349 & 0.339 & 34.922 & 0.000 & 5.909 & 0.000 \\
\hline model2 & 0.572 & 0.327 & 0.317 & 31.630 & 0.000 & 5.624 & 0.000 \\
\hline model3 & 0.587 & 0.344 & 0.334 & 34.085 & 0.000 & 5.838 & 0.000 \\
\hline model4 & 0.562 & 0.316 & 0.305 & 29.992 & 0.000 & 5.476 & 0.000 \\
\hline
\end{tabular}

Table 7. Regression analysis coefficients of object factors.

\begin{tabular}{|c|c|c|c|c|c|}
\hline \multirow{4}{*}{$\begin{array}{l}\text { model } \\
\text { Mode model1 (multiple } \\
\text { linear regression model) }\end{array}$} & \multicolumn{4}{|c|}{ object factors } & \multirow{2}{*}{$\begin{array}{r}\text { standard } \\
\text { Regression standard }\end{array}$} \\
\hline & Asset specificity & uncertainty & frequency & Strategic position & \\
\hline & $b_{1}=0.332$ & $\mathrm{~b}_{2}=0$ is refused & $b_{3}=0$ is refused & $b_{4}=0.382$ & \multirow{8}{*}{$\begin{array}{l}\text { the standard into the equation } \\
\text { is: Probability value of statis- } \\
\text { tics Fshould }<=0.050 \text {; the } \\
\text { standard to remove is }>=.100\end{array}$} \\
\hline & \multicolumn{4}{|c|}{$\mathrm{Y}_{2}=0.332 \mathrm{a}_{1}+0.382 \mathrm{a}_{4}$} & \\
\hline \multirow{2}{*}{$\begin{array}{l}\text { model } 2 \\
\text { (Bi-logarithm model)) }\end{array}$} & $\mathrm{d}_{1}=0.312$ & $\mathrm{~d}_{2}=0$ is refused & $\mathrm{d}_{3}=0$ is refused & $\mathrm{d}_{4}=0.356$ & \\
\hline & $\mathrm{InY}_{4}=0.312 \operatorname{Ina}_{1}+$ & 56 Ina $_{4}$ & & & \\
\hline \multirow{2}{*}{$\begin{array}{r}\text { model } 3 \text { (logarithm } \\
\text { Linear model) }\end{array}$} & $\mathrm{g}_{1}=0.332$ & $\mathrm{~g}_{2}=0$ is refused & $\mathrm{g}_{3}=0$ is refused & $\mathrm{g}_{4}=0.365$ & \\
\hline & \multicolumn{4}{|c|}{$\operatorname{InY}_{6}=0.332 a_{1}+0.365 a_{4}$} & \\
\hline \multirow{2}{*}{$\begin{array}{l}\text { model } 4 \text { (linear } \\
\text { Logarithm model) }\end{array}$} & $\mathrm{i}_{1}=0.309$ & $\mathrm{i}_{2}=0$ is refused & $\mathrm{i}_{3}=0$ is refused & $\mathrm{i}_{4}=0.371$ & \\
\hline & \multicolumn{4}{|c|}{$\mathrm{Y}_{8}=0.309 \mathrm{Ina}_{1}+0.371 \mathrm{Ina}_{4}$} & \\
\hline
\end{tabular}


4) Hypothesis testing results

Testing results Table $\mathbf{9}$.

As in the questionnaire design, outsourcing degrees are low to high ( 1 - 5 points), and the asset specificity is by the unique to the general (1- 5 points); Strategic position is also a high to low scores (1 -5 points), therefore, there is a negative correlation between the asset specificity and strategic position two factors and human resources management outsourcing degree, namely the asset specificity and the strategic position are high, outsourcing degree is low; The asset specificity is low and strategic position is low, the outsourcing degree is high. The results show that when making the human resources management outsourcing decision the enterprise will firstly consider the importance of strategic position of certain management function; outsourcing business that greatly contributes to core competence will increase operational rise of enterprise, therefore, the enterprise is more inclined to deal it with endogenous, this choice also accord with the original intention of enterprise outsourcing, that is centralizing resource to develop core competitiveness. On the other hand, the high asset specificity business often cause larger risk and high cost when enterprise transforming the supplier. Therefore, that must be taken into consideration when the enterprise makes human resources management outsourcing decision. Here to add is, according to the results of the survey, the investigation objects think the asset specificity of human resources management functions from high to low are: job enthusiasm, performance evaluation, position design, salary design and personnel selection; Strategic position from high to low are sorting as: the employees' participation, position design, performance evaluation, personnel selection, salary design.

\section{Conclusion and Management Enlightenment}

\subsection{Research Conclusion}

Human resources management outsourcing is a complex system, which involves many problem and complex relations so that we need take a long-term and in-depth research. In this paper we summarize related theories of human resources management outsourcing, on the basis

Table 8. Regression analysis coefficients of object factors.

\begin{tabular}{|c|c|c|c|c|c|c|c|c|}
\hline & & $\mathrm{R}$ & $\mathrm{R}^{2}$ & after adjusted $\mathrm{R}^{2}$ & F value & F significant & $\mathrm{T}$ value & t significant \\
\hline Model1* & $\begin{array}{c}\text { Strategic position } \\
\text { specificity }\end{array}$ & 0.627 & 0.378 & 0.374 & 63.910 & 0.000 & $\begin{array}{l}8.160 \\
7.092\end{array}$ & $\begin{array}{l}0.000 \\
0.000\end{array}$ \\
\hline Model2 & $\begin{array}{c}\text { Strategic position } \\
\text { specificity }\end{array}$ & 0.489 & 0.239 & 0.234 & 52.060 & 0.000 & $\begin{array}{l}7.421 \\
6.501\end{array}$ & $\begin{array}{l}0.000 \\
0.000\end{array}$ \\
\hline Model3 & $\begin{array}{l}\text { Strategic position } \\
\text { specificity }\end{array}$ & 0.514 & 0.264 & 0.259 & 59.487 & 0.000 & $\begin{array}{l}7.717 \\
7.014\end{array}$ & $\begin{array}{l}0.000 \\
0.000\end{array}$ \\
\hline Model4 & Strategic position & 0.498 & 0.248 & 0.243 & 54.734 & 0.000 & $\begin{array}{l}7.781 \\
6.468\end{array}$ & $\begin{array}{l}0.000 \\
0.000\end{array}$ \\
\hline
\end{tabular}

Table 9. Conclusion.

\begin{tabular}{|c|c|c|}
\hline Pass or not & Hypothes & contents \\
\hline Yes & H11 & $\begin{array}{l}\text { Asset specificity of enterprise human resources management system has significant correlation with human } \\
\text { resource functions outsourcing degree. }\end{array}$ \\
\hline No & H12 & $\begin{array}{l}\text { Uncertainty of enterprise human resources management environment has significant correlation with human } \\
\text { resource functions outsourcing degree. }\end{array}$ \\
\hline No & H13 & $\begin{array}{l}\text { Outsourcing frequency of enterprise human resources management function has significant correlation with } \\
\text { human resource functions outsourcing degree. }\end{array}$ \\
\hline Yes & $\mathrm{H} 21$ & $\begin{array}{l}\text { Strategic position of enterprise human resources management function has significant correlation with its } \\
\text { outsourcing degree. }\end{array}$ \\
\hline No & H31 & Enterprise scale has significant correlation with human resources management outsourcing degree. \\
\hline Yes & H32 & $\begin{array}{l}\text { Top intervention degree in human resources management activity has significant correlation with } \\
\text { outsourcing degrees }\end{array}$ \\
\hline
\end{tabular}


of which we establish a research model of enterprise human resources management outsourcing degree and influencing factors, and prove them through the empirical method; after an econometric analysis, two of subject influencing factors of human resources management outsourcing are refused, and only "top intervention" passes the verification; and two of object factors are refused; "strategic position" and "asset specificity "of the human resources management function respectively pass the inspection.

\subsection{Management Enlightenment}

First, the intervention of top manager to human resources management outsourcing activities will have positive influence to outsourcing degree, that is to say enterprise human resources management outsourcing degree depends largely on top manager's attitude, its decisionmaking power is more concentrated, and the course is from up to down.

Second, enterprise scale and the past outsourcing experience of enterprise have little influence on human resources management outsourcing decision. All kinds of scale enterprise gradually begin to recognize the value and significance, and take different degree of outsourcing strategies according its practical needs.

Third, outsourcing is to pass the non-core business to enterprise external experts to operate; it can save the resources on non-core business to concentrate on the development of the core competitiveness, that viewpoint has been confirmed again in this study. In the field of human resource management outsourcing is also effective, enterprise is more inclined to outsource those low core strength or low strategic position business out.
Fourth, in the three characteristics of trade, the influence of asset specificity on human resources management outsourcing degree is obvious, because human resources management changes at a slower speed relative to the change of outsourcing areas of information technology management and other areas, and it has close contact with the enterprise culture, and enterprise tradition. Therefore, for that human resources management business whose asset specificity is higher and has more enterprise characteristics, if it is outsourced, suppliers may not be able to fully understand the rules and culture in a short time, so outsourcing risk is higher.

Fifth, from the definition of the variables in this research, we can find that there is duplication in concept of peculiarity in the three characteristics of asset specificity and measure of business strategic position of an outsourcing deal, and our empirical test proves that the asset specificity also presents the features except business strategic position and the human resources management outsourcing degree have negative correlation.

\section{REFERENCES}

[1] J. Chen, Core Competence of Corporation: A Literature Review, Science Research Management, Vol. 20, 2009, pp. 20-25.

[2] Q. W. Huang, "Construction of the Enterprise Core Competence and Value Promotion,” The Journal of Quantitative \& Technical Economics, Vol. 4, 2008.

[3] J. Q. Sun, "Research of Outsourcing Level and Influence Factors, Liaoning Economy, Vol. 4, 2006, pp. 38-49.

[4] M. L. Wu, SPSS Statistics Application, Beijing: China Railway Publishing Press, 2009. 